\title{
Prognosis of the Patients in Resuscitation Field in Mali
}

\author{
Broulaye Massaoulé Samaké1, André Kassogué1, Blaise Adélin Tchaou², Aïchata Konaté1, \\ Fadima Kouréissi Tall ${ }^{3}$, Lassina Goita1, Seydina Alioune Beye4, Hamadoun Dicko4, \\ Mamadou Karim Touré5, Mohamed Keita ${ }^{4}$, Dienéba Doumbia ${ }^{4}$
}

\author{
${ }^{1}$ Service of Anesthesia and Resuscitation Teaching Hospital Gabriel Touré, Bamako, Mali \\ ${ }^{2}$ Service of Anesthesia, Resuscitation and Emergencies, Academic Hospitable Center and Department of the Bourgou/Alibori, \\ Parakou, Benin \\ ${ }^{3}$ Service of Anesthesia, Resuscitation and Emergency of the Academic Hospitable Center of Kati, Kati, Mali \\ ${ }^{4}$ Service of Anesthesia, Resuscitation and the Emergencies of the Center Hospitable Academic Point G, Bamako, Mali \\ ${ }^{5}$ Service of Anesthesia Resuscitation and Emergency of the Academic Hospitable Center Luxemburg, Bamako, Mali \\ Email: samakebroulaye@yahoo.fr
}

How to cite this paper: Samaké, B.M., Kassogué, A., Tchaou, B.A., Konaté, A., Tall, F.K., Goita, L., Beye, S.A., Dicko, H., Touré, M.K., Keita, M. and Doumbia, D. (2019) Prognosis of the Patients in Resuscitation Field in Mali. Open Journal of Anesthesiology, 9, 213-220.

https://doi.org/10.4236/ojanes.2019.912021

Received: October 25, 2019

Accepted: December 1, 2019

Published: December 4, 2019

Copyright $\odot 2019$ by author(s) and Scientific Research Publishing Inc. This work is licensed under the Creative Commons Attribution International License (CC BY 4.0).

http://creativecommons.org/licenses/by/4.0/

\begin{abstract}
Introduction: The patients whose vital prognosis is immediately threatened by one or several serious organs failures and consecutive to various pathologies are admitted in resuscitations (IUC). The rates of morbi-mortality are raised in Africa. Objective: To study the prognostic factors. Patient and Methods: It was about a transverse survey from January 2015 to April 2016 in the unit of polyvalent resuscitation of the service of anesthesia resuscitation of the academic hospital center of Gabriel Toure. It included all patient admitted for medico-surgical pathologies of more than three hours of hospitalization. It was about a consecutive recruitment of case. The $\mathrm{Chi}^{2}$ and Fisher tests were used for the comparison of our results with a $\mathrm{p}$ value $=0.05$ considered as meaningful. The consent of the patients or parents was gotten. The survey didn't include a potentially dangerous act. Results: During the period, 624 patients have been collected of which: 50.4\% were medical pathologies, $19.4 \%$ surgical pathologies and $30.2 \%$ of gynéco-obstetric pathologies. At least a complication had occurred in $11.2 \%$. Mortality was of $27 \%$. The sex-ratio was of 0.51 . The middle age was of $31.88 \pm 17,2$ years with extremes of 2 years and 80 years. The met complications were: the scab, the syndrome of acute respiratory distress (ARD), the urinary infection, the pneumopathie, the shock, thrust hypertensive, stops cardio circulatory with respectively $35.1 \%$, $26.6 \%, 22.3 \%, 6.4 \%$ and $3.2 \%$. The middle length of stays was of $4.83 \pm 5.32$ days with extremes of 1 day to 29 days. Conclusion: The complications under hospitalization in unit (IUC) of resuscitation in Mali are a major challenge in term of prevention and management. The potentially non serious pathologies
\end{abstract}


complicate themselves and compromise the vital prognosis.

\section{Keywords}

Morbimortality, Resuscitation, Academic Hospitable Center, Mali

\section{Introduction}

The patients whose vital prognosis is immediately threatened by one or several serious organ failure and consecutive to various pathologies are admitted in resuscitations. This state makes that it is necessary to assure an increased surveillance of the patients and to have some prérequis to know the use of techniques and specific materials, the continuous surveillance and a qualified staff. The modes of admission are variable; they can be direct or by transfer. In Europe, the direct admission of the patients in resuscitation is spilled enough due to the regulation of the emergencies with a frequency of 30\% [1] [2]. To the United States, the importance of the traumatic mortality justified a regional organization of the management of the injured based on the traumas center. The modes of admission of the patients in resuscitation influence on the prognosis of these. The system of the polyvalent resuscitation in the countries of limited resources demand more efficiency. In France the death rate of the patients admitted in resuscitation reaches $20 \%-50 \%$ [3] [4]. In Africa in Burkina the global death rate was of $63.6 \%$ [5]. The death rates observed in Niger, Gabon and Morocco were respectively $28.34 \%$, $27.8 \%$ and $30 \%$ [6]. A previous survey achieved in the service recovered a death rate of $42.5 \%$ [7]. The evaluation of the foreseeable evolution of the patients or even the degree of gravity is a practice in the sense of the quality of the care. So to improve the prognosis of our patients, we initiated this survey with as objective to determine the prognostic factors of the patients in resuscitation.

\section{Patient and Methods}

It was about a prospective and transverse survey from January 2015 to April 2016 in the unit of polyvalent resuscitation of the service of anesthesia resuscitation of the academic hospitable center of Gabriel Toure. The population of survey was constituted of the set of the patients admitted in polyvalent resuscitation unit. Was included all patient admitted for médico-surgical pathologies of more than three hours of hospitalization. It was about a consecutive recruitment of case. The data were collected from the register of hospitalization of the service, from the files of the hospitalized, patients from the daily cards of prescription and surveillance and finally from the results of the para clinics exams achieved. A questionnaire has been assigned to all patients which permitted to collect the sociodemographic, clinical and para clinical data. All patients were examined systematically with a compilation of the different clinical parameters (general state conjunctive, the conscience, score of wakening of Albrètte, the tempera- 
ture, the arterial pressure, the cardiac frequency and the respiratory frequency). The retained diagnoses were regrouped by organ. The $\mathrm{Chi}^{2}$ and Fisher tests were used for the comparison of our results with the value of $p=0.05$ considered as meaningful. The consent of the patients or parents was gotten. The survey didn't include a potentially dangerous act.

\section{Results}

During the period, 624 patients have been collected of which: $50.4 \%$ of medical pathologies, $19.4 \%$ of surgical pathologies and $30.2 \%$ of gynéco-obstetric pathologies. At least a complication had occurred in $11.2 \%$. Mortality was of $27 \%$. The sex-ratio was of 0.51 . The middle age was of $31.88 \pm 17.2$ years with extremes of 2 years and 80 years. The intrahospitol admissions dominated $(91 \%$ of the cases). The three main motives of admission were the post-operative survey, the conscience alteration, and the eclampsia with respectively $25.6 \%, 13.3 \%$ and $10.7 \%$. The patients didn't have any antecedent in $42.9 \%$ of the cases. The met complications were: the scabs, the syndrome of acute respiratory distress (SDRA), the urinary infection, the pneumopathie, the shock, thrust hypertensive, stop cardio circulatory with respectively $35.1 \%, 26.6 \%, 22.3 \%, 6.4 \%$ and $3.2 \%$. The three fashions of exit were: the intra hospital transfert (71.8\%), death (26.8\%) and the exéat (1.4\%). The middle length of stays was of $4.83 \pm 5.32$ days with extremes of 1 day to 29 days.

Patients of 50 years and more died more that the other age groups with $56.5 \%$ of death rate $(\mathrm{P}=0.0001)$. Patients of masculine sex died more that women (41.9\% against $19.3 \% \mathrm{P}=0.0001)$. Mortality was more important among the patients who had medical antecedents with $(\mathrm{P}=0.001)$. Patients admit with a score of Glasgow? $=7$ died more either 56.8\% $(\mathrm{P}=0.0001)$. Complications were noted more frequently in men $(18.1 \%$ against $7.7 \% \mathrm{P}=0.0001)$. The complications were observed to all age groups: less than 20 years (6.9\%), 20 to 40 years (14.7\%), 40 to 60 years $(6.5 \%), 60$ years and more $(17.4 \%)(\mathrm{P}=0.0001)$. The intervening of the complications varied with the length of stay with $5.3 \%$ to 4 days of stay length, 9.5\% for a length between 4 and 7 days and 35.7\% to more of 7 days of stay length. The complications had occurred in $50 \%$ of the cases of direct admission, $6.4 \%$ in case of transfer and $11.2 \%$ in case of mutation $(\mathrm{P}=0.024)$. The exits by mutation according to the age group were from $87.9 \%$ to less of 20 years, $74.8 \%$ between 20 and 40 years, $58.2 \%$ between 40 and 60 years and $43.5 \%$ to more of 60 years $(P=0.0001)$. None of the patients of GLASGOW score of lower to 7 didn't leave by transfer against $3.1 \%$ of the patients of GLASGOW score superior to $8(\mathrm{P}=0.0001)$. Femal patients stayed less than 4 days $(60.1 \%$ of the cases against $41.9 \%)(\mathrm{P}=0.0001)$. The fashions of exit according to the motive of admission, of the diagnosis are mentioned in the Table 1 and Table 2, and the length of stay according to the motive of admission Table 3.

\section{Discussion}

The environment in which we exercise is characterized by a weak medicalization 
Table 1. Discharge mode and admittance reason.

\begin{tabular}{|c|c|c|c|c|c|}
\hline \multirow{2}{*}{$\begin{array}{l}\text { Reason of } \\
\text { admittance }\end{array}$} & \multicolumn{3}{|c|}{ Discharge mode } & \multirow{2}{*}{ Total (\%) } & \multirow{2}{*}{$\mathrm{p}$} \\
\hline & Mutation (\%) & Discharge (\%) & Death (\%) & & \\
\hline $\begin{array}{c}\text { Taken in } \\
\text { post-operative } \\
\text { charge }\end{array}$ & $135(84.4)$ & $0(0)$ & $25(15.6)$ & 160 & 0.0001 \\
\hline $\begin{array}{l}\text { Change of } \\
\text { conscience }\end{array}$ & $43(51.8)$ & $6(7.2)$ & $34(41.0)$ & 83 & 0.0001 \\
\hline Eclampsia & $83(86.5)$ & $0(0)$ & $13(13.5)$ & 67 & 0.002 \\
\hline Malaria & $31(68.9)$ & $3(6.7)$ & $11(24.4)$ & 45 & 0.044 \\
\hline Patient shock state & $37(88.1)$ & $0(0)$ & $5(11.9)$ & 42 & 0.052 \\
\hline Termal burn & $12(34.3)$ & $0(0)$ & $23(65.7)$ & 35 & 0.0001 \\
\hline $\begin{array}{l}\text { Cranial } \\
\text { traumatism }\end{array}$ & $18(60)$ & $0(0)$ & $12(40)$ & 30 & 0.238 \\
\hline $\begin{array}{c}\text { Diabetic } \\
\text { coma }\end{array}$ & $17(58.6)$ & $0(0)$ & $12(41.4)$ & 29 & 0.173 \\
\hline $\begin{array}{c}\text { Cerebral vascular } \\
\text { accident }\end{array}$ & $11(50)$ & $0(0)$ & $11(50)$ & 22 & 0.040 \\
\hline $\begin{array}{l}\text { Poly } \\
\text { traumatism }\end{array}$ & $10(76.9)$ & $0(0)$ & $3(23.1)$ & 13 & 1 \\
\hline Sepsis & $8(100)$ & $0(0)$ & $0(0)$ & 8 & 0.213 \\
\hline Other & $48(71.6)$ & $0(0)$ & $19(28.4)$ & 90 & 0.786 \\
\hline Total & $358(57.4)$ & $168(26.9)$ & $98(15.7)$ & (100) & \\
\hline
\end{tabular}

Table 2. Diagnosis and mode of discharge.

\begin{tabular}{|c|c|c|c|c|c|}
\hline \multirow{2}{*}{ Diagnosis } & \multicolumn{3}{|c|}{ Discharge mode } & \multirow{2}{*}{ Total (\%) } & \multirow{2}{*}{$\mathbf{P}$} \\
\hline & Mutation (\%) & Discharge (\%) & Death (\%) & & \\
\hline $\begin{array}{l}\text { Cardio-vascular } \\
\text { pathology }\end{array}$ & $66(7.0)$ & $0(0)$ & $22(25)$ & 88 & 0.583 \\
\hline $\begin{array}{c}\text { Pulmory broncho } \\
\text { pathology }\end{array}$ & 45 (83.5) & $0(0)$ & $9(16.7)$ & 54 & 0.135 \\
\hline $\begin{array}{c}\text { Neurological } \\
\text { pathology }\end{array}$ & $21(52.2)$ & $0(0)$ & $19(47.5)$ & 40 & 0.013 \\
\hline $\begin{array}{l}\text { Traumatism } \\
\text { pathology }\end{array}$ & $42(43.8)$ & $0(0)$ & $54(56.3)$ & 96 & 0.0001 \\
\hline $\begin{array}{l}\text { Métabolism } \\
\text { pathology }\end{array}$ & $4(18.2)$ & $3(13.6)$ & $15(68.2)$ & 22 & 0.0001 \\
\hline $\begin{array}{c}\text { Obstetric gyneco } \\
\text { pathology }\end{array}$ & $219(84.2)$ & $0(0)$ & $41(15.8)$ & 260 & 0.0001 \\
\hline $\begin{array}{l}\text { Infectious } \\
\text { pathology }\end{array}$ & $45(44.6)$ & $6(5.9)$ & $50(49.5)$ & 101 & 0.0001 \\
\hline $\begin{array}{l}\text { Chirurgical } \\
\text { pathology }\end{array}$ & $157(93.5)$ & $0(0)$ & $11(6.5)$ & 168 & 0.0001 \\
\hline Total & $358(57.4)$ & $168(26.9)$ & $98(15.7)$ & $624(100)$ & \\
\hline
\end{tabular}


Table 3. Duration of hospitalization and admittence reason.

\begin{tabular}{|c|c|c|c|c|c|}
\hline \multirow{2}{*}{$\begin{array}{l}\text { Reason of hospital } \\
\text { admission }\end{array}$} & \multicolumn{3}{|c|}{ Duration of hospitalization } & \multirow[b]{2}{*}{ Total (\%) } & \multirow[b]{2}{*}{$\mathrm{p}$} \\
\hline & $\begin{array}{c}\text { Less than } 4 \text { days } \\
(\%)\end{array}$ & $\begin{array}{c}{[4 \text { à } 7 \text { days }[} \\
(\%)\end{array}$ & $\begin{array}{c}7 \text { days and more } \\
\text { (\%) }\end{array}$ & & \\
\hline Care post-operative & $105(65.6)$ & $41(25.6)$ & $14(8.8)$ & 160 & 0.009 \\
\hline $\begin{array}{l}\text { Conscience } \\
\text { modification }\end{array}$ & $42(50.6)$ & $35(42.2)$ & $6(7.2)$ & 83 & 0.001 \\
\hline Eclampsia & $63(65.6)$ & $26(27.1)$ & $7(7.3)$ & 67 & 0.270 \\
\hline Malaria & $28(62.2)$ & $6(13.3)$ & $11(24.4)$ & 45 & 0.053 \\
\hline State of shock & $26(61.9)$ & $13(31)$ & $3(7.1)$ & 42 & 0.282 \\
\hline Thermal burn & $22(62.9)$ & $8(22.9)$ & $5(14.3)$ & 35 & 0.791 \\
\hline $\begin{array}{c}\text { Cranial } \\
\text { traumatism }\end{array}$ & $4(13.3)$ & $2(6.7)$ & $24(80)$ & 30 & 0.0001 \\
\hline Diabetic coma & $15(51.7)$ & $2(6.9)$ & $12(4.6)$ & 29 & 0.0001 \\
\hline $\begin{array}{c}\text { Cerebral vascular } \\
\text { accident }\end{array}$ & $3(13.6)$ & $7(31.8)$ & $12(54.5)$ & 22 & 0.0001 \\
\hline Poly traumatism & $1(7.7)$ & $12(92.3)$ & 0 & 13 & 0.0001 \\
\hline Sepsis & $5(62.5)$ & 0 & 3 & 8 & 0.097 \\
\hline Other & $30(44.8)$ & $25(37.3)$ & $12(17.9)$ & 67 & 0.070 \\
\hline Total & $358(57.4)$ & $168(26.9)$ & $98(15.7)$ & $(100)$ & \\
\hline
\end{tabular}

of the population, the limitation of the therapeutic means and the very precarious socio-economic level. Mortality is of $27 \%$ against $42.9 \%$ in the survey of Samaké B.M. [7]. This difference may be explained by the predominance of the young people in our survey that is very often admitted for the acute pathologies and without factor of comorbidity. The patients are younger in our set. On the other hand in the set of Samaké B.M. [7] the patients besides 60 years predominated. This difference results in one way from the frequency of the admissions for frequent obstetric pathologies among the young people and admissions for accident of the public way where the young people are implied on the other way. The femal predominance is noted in the sets of Ouédraogo and Colls [5] and of Samaké B. [7]. the fashion of admission is dominated by the mutations. This mode of entry is compatible with the poluvalent character of the resuscitation that receives the patients of all services of the academic hospitable center. The postoperative survey and the éclampsia are of the most frequent motives of admission. This high nember of patients after interventions is largely due to the lack postinterventionnel room surveillance. The unit of resuscitation that acted as setting of the survey has a most elevated level of the sanitary pyramid of Mali that puts us in position to receive the complications related to pregnancy notably the very frequent eclampsia again in Africa especially in Mali. The intervening of the complications during hospitalization is one of the elements of appreciation of the quality of the care. They are dominated by the complications of decubitus and the infections. This result denotes the insufficiency of the technical materials 
notably the anti-scab mattresses and the absence of a strategy of prevention of the infections related to the care. The middle length of stay was of $4.83 \pm 5,32$ days. It is comparable to those noted in the literature with middle lengths of variable stay between 4 and 10 days [8] [9] [10] [11]. This relatively short length is due to the predominance of the admission motives as the post-operative surveillances and the eclampsia. In these two cases the stays are relatively short and a less important mortality. This is as much true as some studies found that the patients who have an elevated initial gravity have a longer stay length [12]. The length of the stay is often used like alternative to measure the morbidity, but it is always tributary of the policies concerning exit, therapeutic habits and management of the beds [13].

The evolution of the patients correlated to the following diagnoses: broncho-pulmonary, neurological, traumatic, metabolic, gynéco-obstetric, infectious, and surgical with $\mathrm{p}<0.05$. The patients survive a lot of majoritary when it is about gynéco-obstetric and surgical pathologies. On the other hand they die more when it is about infectious, metabolic and traumatic pathology from where the necessity to reinforce the technical material to face these pathologies. This evolution is also correlated to the complications with $100 \%$ of death for complications of pneumopathie and shock with $\mathrm{p}<0.05$. Hajar $\mathrm{T}$ [14] found $60 \%$ of complication of pneumopathie. The complications to type of scab, urinary infection and pneumopathies are related to the sex with a statistically meaningful test. The urinary infections and the pneumopathies occur to $100 \%$ at the men and the scabs are observed majoritary at the men. The anatomical particularities make that the men are exposed to the urinary infections more. Also considering the short stay length at the women in reason often of the motives of amission, they are less exposed. The shock occurred besides to $100 \%$ among the subjects of 60 years. It could be explained by the existence of the factors of comorbidity to these ages that are not often identified before because of the under medicalization of the population. The intervening of the scabs is correlated to the fashion of entry with a frequency of $90.9 \%$ in case of admission by transfer and $9.1 \%$ in case of direct admission against $0 \%$ in case of admission by mutation. The transferred patients very often stayed in other structures without the adequate means. They arrive with a beginning of scab for most, what puts the problematic of the quality of the care upstream of the structures of last reference. The modes of exit were related to the motives of admission. It is about the admission motives as post-operative surveillance, the conscience alteration, the eclampsia, the malaria, the thermal burn and cerebral vascular accident. Except in burn patient where the death rate is more high, in all others cases the patients go out majoritary by mutation. According to the diagnosis the modes of exit are different with $\mathrm{P}<0.05$

\section{Conclusion}

The intervening of the complications under hospitalization in unit of resuscita- 
tion in Mali is a major challenge in term of prevention and management. The pathologies treated that are not potentially serious complicate themselves and compromise the vital prognosis. We recommend an enhancement of technical platform a good strategy of prevention and treatment of the infections related to the care.

\section{Conflicts of Interest}

The authors declare no conflicts of interest regarding the publication of this paper.

\section{References}

[1] Telion, C., Greffet, A., Rozenberg, A., Lejay, M., Jannière, D. and Carli, P. (2000) L'admission directe en service de réanimation ou de soins intensifs des patients pris en charge par le SMUR est-elle justifiée? Annales Françaises d'Anesthésie et de Réanimation, 19, 654-661. https://doi.org/10.1016/S0750-7658(00)00294-X

[2] Meyer, A.A. (1998) Death and Disability from Injury: A Global Challenge. Journal of Trauma, 44, 1-12. https://doi.org/10.1097/00005373-199801000-00001

[3] Knaus, W.A., Wagner, D.P., et al. (1982) A Comparison of Intensive care in the USA and France. Lancet, 2, 642-646. https://doi.org/10.1016/S0140-6736(82)92748-9

[4] Lemeshow, D., Teres, S., Pasdites, H., Avrunin, J. and Steingrub, J. (1985) A Method for Predicting Survival ant Mortality of IUC Patients Using Objectively Derived Weights. Critical Care Medicine, 13, 519-525. https://doi.org/10.1097/00003246-198507000-00001

[5] Ouedraogo, N., Niakera, A., Somne, A., Svetlana, B., Ouedrago, H. and Joahim, S. (2002) Cahier d'étude et de recherche francophone. Santé, 4, 375-827.

[6] Ruttiman, M. and Kowalski, J.J. (2001) Evolution du transport sanitaire d'urgence au cours des conflits armés. JEPU, Arnette, Paris.

[7] Samaké, B.M., Togo, A., Diallo, B., Almemoun, A., Touré, M.K., Togola, M., Kéita, M., Diani, N., Tall, K., Dembélé, S.A., Doumbia, D. and Diallo, A.K. (2016) Patient de réanimation au centre hospitalier Universitaire Gabriel Touré: Aspects cliniques et pronostiques. Ramur, 21, 63-66.

[8] Fok, A., Tan, Y. and Ong, Y. (1992) Medical Intensive Care unit Utilization in an Acute Teaching Hospital. Singapore Medical Journal, 33, 21-23.

[9] Ensminger, S.A., Morales, I.J., Peters, S.G., Keegan, M.T., Finkielman, J.D., Lymp, J.F. and Afessa, B. (2004) The Hospital Mortality of Patients Admitted to the ICU on Weekends. Chest, 126, 1292-1298. https://doi.org/10.1378/chest.126.4.1292

[10] Misset, B., Naiditcb, M., Saulnier, F., Fosse, J.P., Pinsard, M., Harari, A., Blériot, J.P., Comar, L., Garrigues, B., Attali, C. and Guincestre, M.C. (1997) Construction d'une classification diagnostique pour le groupage médico économique des patients de réanimation Informatique et Santé. Informatique et Gestion Médicalisée, 9, 39-46. https://doi.org/10.1016/S0750-7658(97)86346-0

[11] Boffelli, S., Rossi, C., Aughileri, A., Giardino, M., Carnevale, L., Messina, M., Neri, M., Langer, M. and Bertolini, G. (2006) Continuous Quality Improvement in Intensive Care Medicine: The GiViTI Margherita Project. Minerva Anestesiologica, 72, 419-432.

[12] Branger, B., Durand, C., Jarno, P., Chaperon, J. and Delattre-Maillot, I. (2002) 
Mortalité hospitalière imputable aux infections nosocomiales. Médecine et Maladies Infectieuses, 32, 98-106. https://doi.org/10.1016/S0399-077X(01)00326-2

[13] Deuxième conférence de consensus européenne en réanimation et médecine d'urgence. Facteurs pronostiques chez les malades de réanimation. 09 au 10 Décembre 1993. Maison de la chimie Paris (France).

[14] Moreno, R.P., Matmitz, P.G.H., Almeida, E., Jordan, B., Bauer, P., Campos, R.A., Iapichino, G., Edbrooke, D., Capuzzo, M. and Le Gall, J.R. (2005) SAPS 3-From Evaluation of the Patient to Evaluation of the Intensive Care Unit. Part 2: Development of a Prognostic Model for Hospital Mortality at ICU Admission. Intensive Care Medicine, 31, 1345-1355. https://doi.org/10.1007/s00134-005-2763-5 